\title{
SEYYÎD VEHBÎ'NIIN MANZUM HADİS-İ ERBA'İN TERCÜMESİ
}

\begin{abstract}
Öz
Arap ve Fars edebiyatında Hz. Peygamber'in merkezde olduğu edebi türlerden biri olan kırk hadisler, Türk edebiyatı şair ve nâsirlerince de sık sık işlenmiştir. Divan edebiyatında ise daha çok bu türün manzum örneklerine rastlamaktayız. Vehbî de bu türde orta seviyede başarılı bir eser ortaya koymuş şairlerimizdendir.

Seyyid Vehbî on yedinci yüzyılın son çeyreği ile on sekizinci yüzyılın ilk yarısında yaşamış; Anadolu kazaskeri olan Osman Efendi'nin mülazımlığını yapmış çeşitli konularda eserleri bulunan âlim - şair bir şahsiyettir. Üçüncü Ahmed'e yazmış olduğu sıhhatnâmelerle padişahın ilgisini ve takdirini kazanmıştır. Bu makalede Seyyid Vehbî'nin manzum kırk hadis tercümesi konu edilmiştir. $\mathrm{Bu}$ eser geniş manalı hadisleri kırk kıt'a şeklinde açıklamaktadır. Günümüzde bu eserin tespit edilebilen tek nüshası elde edilmiş olup İstanbul Üniversitesi Nadir Eserler Kütüphanesi'nde yer almaktadır. Çalışmada ilgili kırk hadis tercümesinin transkripsiyonlu metninin yanı sıra Seyyid Vehbî’nin hayatı, edebi kişiliğgi, eserleri ve bu metnin içeriği hakkında bilgi verilmektedir.
\end{abstract}

Ahmet ÇOLAK ${ }^{*}$

Anahtar Sözcükler: Hadis, Kırk Hadis, Manzum Kırk Hadis, Seyyid Vehbî.

\section{TRANSLATION OF POETICAL "HADIS-I ERBA'IN" BY SEYYID VEHBI}

Abstract

Forty Hadiths, one of the sample of literal works based on The Prophet Muhammad subjected in Arabic and Iranian Literature, is also mentioned very often by poets and authors in Turkish Literature.

We may come across mostly poetical examples of this genre in Divan Literature. Vehbi is one of the poets who produced partly successful literal works in that genre. Seyyid Vehbi is a scholar and poet who has some literary works about different subjects worked as a lieutenant of Anatolian Qadı'asker Osman Efendi and lived between last quarter of 17th century and first half of 18th century. He was appreciated by Sultan writing "sihhatname's" which were attributed to Ahmet The Third. In this article, "Translation of Hadis-i Erba'in" is studied. This work explains hadiths with a broad meaning in forty stanzas. Nowadays, the only found copy of this work exists in the library of Rare Works in Istanbul University. This study contains not only related text of the translation of forty hadiths with transcription but also life, literary personality and works of Seyyid Vehbi and contents of the work.

Keywords: Hadith, Forty Kadith, Verse Forty Hadisth, Seyyid Vehbi.

\footnotetext{
* Arş. Gör.; Süleyman Şah Üniversitesi, Türk Dili ve Edebiyatı Bölümü, acolak@ @ssu.edu.tr.
} 


\section{Giriş}

Türk kavimlerinin İslamiyet ile tanışmaları sekizinci yüzyılda olmuştur. Bu tanışma daha sonraki dönemlerde Türklerin topluluklar hâlinde İslamiyet'e geçmeleri şeklinde devam etmiştir. İslamiyet'e geçişten sonra içtimai, beşerî ve sosyal hayatta dinî değişiklik yaşanmış ve Türk toplumlarında İslamiyet'ten önce de hâkim olan tek Tanrı inancı bu değişimi hızlandırmıştır. Sosyal ve içtimai hayatta olan bu yenilikler, ilerleyen zaman içerisinde Türk edebiyatını da etkilemiş ve bu edebiyatın temel konuları hâlini almıştır.

İslamiyet'i kabul etmek kişileri değiştirdiği gibi bu değişikliklerin merkezinde olan insanların yaşadığı toplumun da değişmesi kaçınılmazdır. Bu değişimler sadece edebî yönde olmayıp mimari, resim ve müzik gibi sanatsal ve hissî açıdan hassasiyete sahip olan bütün dallarda gerçekleşmiştir.

İslamiyet'i kabul ile birlikte değişen edebiyatımız, birçok tarihçi ve edebiyatçı tarafından çeşitli özellikler gözetilerek dönemlere ayrılmıştır. Bu tasniflerin içinde en yaygını, "İslamiyet Öncesi Türk Edebiyatı, İslamiyet Sonrası Türk Edebiyatı ve Batı Etkisindeki Türk Edebiyatı", şeklinde üç ana dönem olarak yapılan tasnif ve tavsiftir. Bu dönemleri yazılı eserler açısından değerlendirecek olursak, tarihî süreçte en çok eser verilen dönemin "Íslamiyet Etkisindeki Türk Edebiyatı Dönemi" olduğu göze çarpmaktadır. İslamiyet sonrası değişime uğrayan Türk edebiyatı, şekil ve içerik açısından daha önceki dönemden farklılıklar arz etmektedir. Bu dönemi muhteva yönünden değerlendirmeye tabi tutacak olursak İslam peygamberi $\mathrm{Hz}$. Muhammed, bu dönem edebiyatı ürünlerinin en önemli konuları arasında yer almaktadır. Türkler, İslamiyet'i kabul ettikten sonra yeni dinine diğer toplumlardan fazla sahip çıkmış ve onu her alanda geliştirip daha da büyütmek için çalışmalarda bulunmuşlardır.

İslamiyet ile birlikte daha önceki dönemlerde hiç olmadığı kadar Arap ve İran toplumlarıyla münasebet kuran Türk toplumları, bu dönemden sonra maddi ve manevi açıdan daha fazla ilişki içerisine girerek bu toplumların diğer yönlerinden olduğu gibi edebiyatlarından da etkilenmişlerdir. Gazel, kaside ve mesnevi gibi temel türler bu Müslüman toplumlardan bizim edebiyatımıza geçmiş; birçok edebi tür ve şekil, Türk edebiyatı içerisinde değişik coğrafyalarda yerini almıştır. Bundan dolayı bu dönemlere bazı edebiyatçılarımız "Dîn̂̂ Edebiyat, İslami Türk Edebiyatı veya Ümmet Çă̆ı Edebiyatı" vs. şeklinde isimler vermişlerdir.

Bu dönemlerin büyük bir kısmını Osmanlı devleti içinde gelişen "Divan Edebiyatı veya Klasik Türk Edebiyatı” olarak adlandırdığımız dönem oluşturmaktadır. Osmanlı Devleti'nin yıkılıp Türkiye Cumhuriyeti’nin kurulması ile birlikte İslamiyet, dönem şartlarının da etkisi ile Cumhuriyetin ilk yıllarında yerini daha başka konulara bırakmıştır. Ancak, İslami muhteva 
etkisini göstermeye devam etmiştir. Dinî içerikli şiir yazan hatta divan şiir geleneği içerisinde ürünler veren şairler yetişmeye az da olsa devam etmiştir.

İslamiyet sonrası Türk edebiyatında hece vezninin yanı sıra aruz vezni de kullanılmaya başlanmıştır. Bununla birlikte gazel, kaside, mesnevi gibi birçok nazım şekli Türk edebiyatı içerisindeki yerini almıştır. Nazım şekillerinde olan etki, içerikte kendisini daha fazla göstermiş; Kur'an, sünnet ve hadisler zamanla bu edebiyatın temel kaynağı hâline gelmişlerdir. Dolayısıyla dinî kaynakları konu edinen birçok edebî tür gelişmiştir. Bu tür edebî eserlerde, Hz. Peygamber'in birçok yönü ele alınmıştır. Savaşları, doğumu, hayatı, sözleri, yaşamı, bedeni, sünnetleri ve vefatı çok yönlü olarak en güzel cümleler aracı ile bedii bir zevkle anlatılmaya çalışı1mıştır. Hz. Muhammed sevgisi ile yazılan bu eserler, döneminde en fazla talep olunan eserler hâline gelmiştir.

Cemal Kurnaz bu mevzuyu şu cümleleri ile izah etmiştir: "Ecdadımız dini, bir dünya görüşü olarak bütün hayata hâkim kılmıştı. Eşyayı, kâinatı onun penceresinden bakarak yorumlamışlar, anlamlandırmışlardı; bunu yaparken de dili yeniden yoğurmuşlardı. Bunun sonucu olarak da herkesin anladığı bir mecazlar sistemi meydana gelmişti (1997: 281).”

$\mathrm{Bu}$ eserlerin büyük çoğunluğu manzum eserler olmakla birlikte, dinî içerikli mensur eserler de hiç azımsanmayacak ölçüdedir. Manzum veya mensur bu eserlerden birkaçı, Allah'ın birliğini işleyen tevhitler, kulun Allah’tan af ve bağışlama talebinin dile getirildiği münacatlar, Allah'ın güzel isimlerinin sıralandığı yahut şerh edildiği Esmâ-i Hüsna türü eserler, Kur'an tercümeleri şeklindedir.

“Cenâb-1 Hak ve Kur'an-1 Kerim” dışında İslami Türk edebiyatının muhteva itibari ile bu makalenin de asıl konusu olan kırk hadis; yanı sıra mevlid, esma-i nebi, şefâatnâme, hicretnâme gibi türlerin kaynağı da Hz. Muhammed'dir.

Kırk hadisin hem edebiyat hem de hadis ilmi içerisinde önemli bir yeri vardır. Bir kısmı muhaddis, bir kısmı farklı ilim dallarında ihtisas sahibi âlim, az bir kısmı da sıradan kimseler olmak üzere pek çok kişi bu konuda eser telif etmiştir (Yıldırım, 2000: 33). Hz. Muhammed'in "Ümmetimin dinî işlerine dair kırk hadis ezberleyeni Allah kıyamet günü fakihler ve âlimler zümresiyle haşreder." mealindeki hadisi, hadis âlimlerince rivayeti zayıf hadisler arasında gösterilmesine rağmen kırk hadis derlemelerinin ortaya çıkışında başlıca amil olmuştur (Gıynaş, 2012: 1134). Kırk hadis şeklinde manzum veya mensur oldukça fazla eser yazılmıştır. Bu türün yazılış sebebi, ortaya çıkışı, derlenirken neler gözetildiği gibi birçok konu vardır. Bütün bu konulara değinmek makalenin hacmini aşacağından ve usulü değiştireceğinden kısaca açıklamakla iktifa edeceğiz. 
Bu yazıda Seyyid Vehbî’nin Hz. Peygamber'in kırk hadisini tercüme eden manzum kırk hadisi tanit1lacak ve eserin metnine yer verilecektir.

\section{Eserin Müellifi ve Hayatı}

Eserin hatimesinde geçen "Umarum oḳuya Vehbiye raḥmet" ibaresinden ve on sekizinci hadisin "Kavl-i Vehbìye gūş-ı rag̉bet tụt" otuz üçüncü hadisin "Ṭta nuṣh-ı Vehbīye gūş-ı kabūl” mısralarından anlaşıldığı üzere eser Vehbî’ye aittir. Bilindiği gibi Vehbî mahlaslı iki Divan şairimiz bulunmaktadır. Bunlardan ilki 1674 - 1736 arasında yaşayan Seyyid Vehbî, ikincisi ise 1718 - 1809 yılları arasında yaşayan Sünbülzade Vehbî’dir. Eserin müellifinin Vehbî mahlaslı şairlerden Seyyid Vehbî’ye ait olduğunu ilk olarak Abdülkadir Karahan belirtmiştir (Karahan, 1966: 545). Seyyid Vehbî hakkında daha sonradan çalışma yapan kimseler bu bilgiden hareketle eserin Seyyid Vehbî’ye ait olduğunu kabul etmişlerdir (Dikmen, 2004). Ancak Karahan, aynı eserin varlığından "İslâmî Türk Edebiyatında Kırk Hadis" adlı kitabında bahsetmez (Karahan, 1991).

Seyyid Vehbî’nin asıl adı Hüseyin olup İstanbul'da doğmuştur (bk.: Altuner, 1989). Ali Canip Yöntem, Kabataşlı olduğunu da belirterek detaylı bilgi verir (Sevgi-Özcan, 1996: 264). Doğum tarihi hakkında bilgi yoktur. Ancak mülazım olduğu tarih düşünülerek ve o sırada 20 23 yaşlarında olduğu kabul edildiğinde H.1085 / M1674? y1lında doğmuş olduğu söylenebilir (Dikmen, 2004: 3).

Silsilesi ehl-i beytten Hüsammeddin Efendi'ye dayandığı için Hüsamî mahlasını kullanmıştır. Daha sonra yeni mahlas aramış ve hocası Mirza-zâde Ahmed Neylî ona Vehbî mahlasını vermiştir. Ali Canib Yöntem, bunu şu şekilde ifade eder:

... anası tarafından nesli erbâb-1 mücâhedenin serbülendi Hasan Hüsammeddin Efendinâm pîr-i azîze müntehi olur. Bunun için gençliğinde Hüsâmî mahlasını kullanmış, hatta ceddi siyâdet ashabanından sayıldığıdan Üçüncü Ahmed'e verdiği bir kasidenin sonunda:

İdüp sipârişini gayra mâ-bihi’t-tercih

Hüseyn Vehbîyi eyle müfettiş-i Haremeyn

dediği gibi Seyyid unvanını da aynı sebeple isminin başına geçirmiştir (Sevgi - Özcan, 1996: 266).

Vehbî iyi bir eğitim görmüş; derslerini Mirza-zâde Şeyh Mehmed Efendi'den almıştır. Daha sonra Kazasker Abdülbakî Arif Efendi'den hat dersi alır. Mektupçu, tezkireci ve kassamlık görevlerinde bulunan şair, Hoca-zâde Seyyid Osman Efendi'nin Anadolu kazaskerliği döneminde H.1108 / M.1696 tarihinde mülazım olmuştur. Daha sonra Hoca Hatun 
Medresesi'ne müderris olmuştur (H.1123 / M1711). Akabinde takdir edilerek Şerife Hatun Medresesi'ne nakledilerek derecesi yükseltilmiştir. Göze giren şair, İbrahim Paşa sayesinde Hüsrev Kethüda Medresesi'ne müderris olur ve aynı sene içerisinde Sahn-1 Seman Medresesi'ne tayin edilir (Dikmen, 2004: 4).

İbrahim Paşa'nın tercüme komisyonunda yer alan şair, Aynî Tarihi'ni çeviren heyet içerisinde yer alır ve bu esnada naiplik göreviyle Halep'e gider (Banarlı, 1971: 753).

Hacca giden şair Hicaz dönüşü Halep’ten ayrılıp İstanbul'a gelirken hastalanır ve Aksaray'daki evinde H.1149 / M.1736 yılında ölür. Canbâziye Mescidi haziresine defnedilmiştir. Suyolcu-zâde Mehmed Necip Efendi’nin şu beyti ölüm tarihidir:

Ah Vehbî-i hüner-pîşe cihandan gitdi

Göçdi ‘ukbâya emîrü'ş-şu'ar’a-1 dânâ (H.1149) (Sevgi - Özcan, 1996: 268).

\section{Edebî Kişiliği ve Eserleri}

Vehbî, Divan edebiyatının mühim şairlerinden biridir. Padişah fermanıyla reîs-i şâiran seçilen Osman-zâde Tâib onu "ma 'nâ mülkünün padişahı" olarak görmektedir. Zira şu beytiyle kendisinden sonra reîs-i şâiran olacak kişinin Seyyid Vehbî olması gerektiğini belirtir:

Vekîlümdür benüm Vehbî-i mu'ciz-dem beyân itsün

Sunûf-1 tâze-gûyânı gürûh-1 yâre yâve-destânı (İnce, 2005: 249).

Üç dile de hâkim olan şair, tezkire şinaslar tarafindan takdir edilen bir şahsiyettir. Vehbî oldukça kolay yazabilen olması yönüyle dikkatleri çeker. Hacimli divanı ve sayıca çok olan eserleri bunu açıkça göstermektedir. Gazelde Nabî, kasidede ise Nef'î tarzında yazmakla övünür. Gazellerinin neşeli, şen ve rind yönüyle Nedim'i, didaktik mesaj verici yönüyle Nabî’yi andırır. Nabî’yi üstat kabul eden şair bunu birçok şiirinde dile getirmiştir:

Sirr-1 kemâli bizde nola eylese zuhûr

Nâbî Efendinün ki babamuz budur bizüm (Dikmen, 2004: 13).

Üretkenliğini belirttiğimiz şairin bugün tespit edilebilen altı eseri vardır. Bu eserler içerik olarak geniş ve zengindir. Eserleri şunlardır:

1.Divan: Karşılaştırmalı metni Hamit Dikmen tarafından doktora tezi olarak hazırlanan eser mürettep bir divanda bulunması gereken özellikleri barındırmaktadır (Dikmen, 1991). Divanda bir münâcat, dört na't, bir mi'râciyye, beş tevhid, seksen altı kaside, bir takriz, dört arz1 hal, iki mektup, yüz yirmi sekiz tarih manzumesi, iki terkîb-bend, iki tercî-bend, iki müseddes, yirmi tahmis, dört şarkı, iki yüz altmış altı gazel, elli bir kıta, on dokuz lügaz, yetmiş beş rübâî yer almaktadır. 
2.Surnâme: Üçüncü Ahmed'in oğullarının sünnet düğünlerinin günü gününe anlatıldığ1 eseridir. Şair, eserde ayrıntılara yer vermekte, İstanbul'u anlatmakta, dönemin örf ve adetlerini tanıtmaktadır. Eser metni üzerine Ahsen Tuba Kaynarca tarafından yüksek lisans tezi yazılmıştır. Bu yüksek lisans çalışmasından önce Recep Ekrem Koçu tarafından da eser özet şeklinde yayımlanmıştır (bk: Kaynarca, 2000; Koçu, 1939).

3.Takriz: Safâyî Tezkiresi'ne yazmış olduğu takrizdir (Dikmen, 2004: 11).

4.Leylâ vü Mecnun: Kaynaklarca ismi zikredilse de henüz herhangi bir nüshası tespit edilememiştir. Eserin Kaf-zâde Faizî tarafından yazılmaya başlanıp Vehbî tarafından tamamlandığını Bursalı Mehmed Tahir aktarmaktadır. ${ }^{1}$

5. Sulhiyye: H.1130 / M.1718 yılında imzalanan Pasarofça Antlaşması hakkında İbrahim Paşa'nın isteği üzerine kaleme alınmıştır. Bu manzum risale Belgrad'ın kaybedilişini anlatmaktadir. $^{2}$

\section{Kırk Hadis Tercümesi}

Şair hakkında bilgi veren tezkirelerde ve biyografik eserlerde bu manzum tercümeden bahsedilmez. Bu eserler dışında Abdülkadir Karahan'ın (1991) ve Selahattin Yıldırım'ın (2000) eserlerinde de bahsi geçmemektedir. Bahsedilmemesi normal bir durumdur. Manzum veya mensur kaleme alınmış olsun kırk hadisler küçük eserler oldukları için kitap hâlini alamamışlar; istisnalar dışında küçük risaleler şeklinde kalmışlardır. Bundan dolayı Divan edebiyatı dönemi içerisinde yazılmış birçok kırk hadis kataloglarda yerini alamamıştır. Yazma eserler barındıran kütüphanelerin katalogları hazırlandıkça yeni kırk hadis tercümesi türünde eserler ortaya çıkmaktadır.

Seyyid Vehbî’nin kırk hadis tercümesinin tek nüshası İstanbul Üniversitesi Nadir Eserler Kütüphanesi TY:1376 numaralı mecmuanın $3^{\mathrm{b}}-6^{\mathrm{a}}$ varakları arasında yer almaktadır. Bu nüshada her hadis metni bir kıta içinde açıklanmıştır. Bu hadislerin Arapça hâli aynı kıtanın üçüncü veya dördüncü mısraında iktibas edilmiş şekilde yer alır. Herhangi bir dibace veya mukaddime barındırmayan eser yedi beyitlik bir hatime ile sona erer. Bu nüsha eksik bir nüsha olabileceği gibi şair tarafından bu şekilde de bitirilmiş olması söz konusudur.

Eserde dört farklı vezin kullanılmıştır. Hadis kısmında yirmi bir kez "fâ 'ilâtün fầ 'ilâtün fâ'ilün", dört kez "fấilâtün fâ'ilâtün fâ'ilâtün fâ'ilün”, dokuz kez "fe 'ilâtün mefâ' 'ilün fe'ilün" altı kez "mefầilün mefâ'ilün fe'vilün” vezni kullanılmıştır. Aynı şekilde hatime bölümünün vezni de "mefâ'ilün mefầilün fe'ûlün”dür.

\footnotetext{
${ }^{1}$ Bursalı Mehmed Tahir, Osmanlı Müellifleri, C. II, s. 354.

2 İstanbul Üniversitesi Nadir Eserler Kütüphanesi TY:2711, vr.220 ${ }^{\mathrm{b}}-229^{\mathrm{b}}$. 
Şair, eserde yer alan hadisleri seçerken insanın kendisi ve çevresindeki kişilerle olan durumuyla ilgili olanları tercih ettiği gözlenir. Bu hadislerin ilim, günah, ibadet, tasavvuf, iyilik, yalan söylememe, söze sadık olma gibi konular için söylendikleri görülür.

Eserde yer alan hadislerin bir kısmının $(6,19,20,26,28,33)$ Türk şairlerce birçok defa tercüme edilen ve yol gösterici olarak kabul edilen Molla Câmî'nin Erba'în'inde (bk: Sevgi, 2000) yer alan hadisler olduğu görülmektedir. Eserde yer alan hadisler daha önce başka şairler tarafından da tercüme edilen hadislerdir. Mesela iki numaralı hadis aynı şekilde Hanif'in eserinde de yer almaktadır (bk: Aksu, 2004).

Eserde yer alan hadislerin birçoğunun kaynağı tespit edilmiş ve dipnotta belirtilmiştir. Kaynağı tespit edilemeyen hadislere aynı şekilde dipnotta "kaynağı tespit edilememiştir" şeklinde not düşülmüştür. Kaynağı tarafımızca tespit edilememiş olması hadisin sahih veya sahih olmaması gibi bir durumunu kesinlikle ortaya koymamaktadır. Ayrıca her hadisin Türkçe meali, ilgili kıtanın dipnotunda verilmiştir. ${ }^{3}$

Vehbî, bu eserini niçin yazdığını ve ne gibi bir arzusunun olduğunu hatimede açıklar. Şair, Allah'tan rahmet, okuyandan dua ve Hz. Peygamber'den şefaat beklediğini ifade eder. Yine bu bölümde "İdüp encāma h̆àme yazdl temmet" ve "Temām olur eger 'ayn-i 'ināyet" mısralarında yer alan "temmet" ve "tamam" ifadeleriyle kırk hadis tercümesini bitirdiğini belirtir.

Eserde, başlık ve her kıta içinde yer alan hadislerin Arapça hâli kırmızı mürekkeple yazılmıştır. Ayrıca ilk yedi kıtada yine kırmızı mürekkeple yazılmış başlıklar yer alır. Bu başlıklar Arapça sayı numaraları şeklindedir. Eser, aharlı kâğıda çift sütun şeklinde nesih yazı ile yazılmıştır. Sekizinci kıtadan itibaren başlık yer almaz. Eserin son varağında ise yazma eserin bittiğini gösteren "temmet (تمت )" kaydı "mim (ح)" şeklinde düşülmüştür. Bilindiği gibi

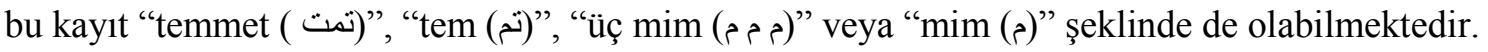

Seyyid Vehbî’nin eseri, Gelibolu Alî, Feyz-i Kefevî ve Okçu-zâde gibi müelliflerin tercümelerine benzemektedir. Vehbî'de onlar gibi her hadisi ayrı bir şekilde vermek yerine her ne kadar zorluğu olsa da Arapça metni aynı kıta içerisine sıkıştırmıştır. Vezin ve kafiye açısından bu durumun şairi oldukça zorladığ 1 farklı farklı aruz ölçüleri kullanmasından anlaşılmaktadır. Ancak Arapça metni mısraa sıkıştırması Vehbî’nin şairlik kudretini ortaya koymak için başvurmuş olduğu bir yöntem olarak da düşünülebilir. Bundan dolayı zaman zaman mısralarda veznin aksadığı görülmektedir.

\footnotetext{
${ }^{3}$ Hadislerin transkribe edilmesi, Türkçeye çevrilmesinde ve ilgili hadis kitabından kontrol edilmesi gibi durumlarda yardımlarını esirgemeyen ancak isimlerini buraya yazmamıza dahi rıza göstermeyen mütevazı hocama teşekkürü borç biliriz.
} 


\section{Sonuç}

Hz. Peygamber'le ilgili olan bu tür, Klasik Türk edebiyatının her döneminde oldukça ilgi görmüştür. Bu tür eserlerin tespit edilmiş ve yayımlanmış olanlarının yanında hâlâ mecmua veya risaleler içerisinden yeni kırk hadislerin ortaya çıkması bu ilgiyi göstermektedir. Bundaki en büyük etkenlerden biri de şüphesiz Hz. Peygamber'in kırk hadis ezberlemenin fazileti ile ilgili söylemiş olduğu -her ne kadar sahihliği hususunda şüpheler bulundursa da- sözüdür.

$\mathrm{Bu}$ çalışmada, tezkirelerde varlığı bilinmeyen, yapılan çalışmalar sonucu ortaya çıkan Seyyid Vehbî'nin manzum kırk hadis tercümesi edebiyat sahasına sunulmuş olacaktır. Bu eser gerek şekil gerekse içerdiği hadisler bakımından Câmî ekolünden gelen bir tercüme intibaı uyandirmaktadir.

Seçilen hadisler tek bir konu üzerine olmayıp birçok konuyla ilgili ögüttleri içerdiği gözlemlenir. Seçilen hadislerin çoğunluğu hadis rivayet eden kaynaklarda yer almaktadır. Hadis olarak verilen iki sözün Hz. Muhammed'e ait olmadığı hususundaki şüpheler olması nedeniyle bu durum dipnotta belirtilmiştir. Bazı hadisler ise mısraa sığdırılma zorunluluğu bulunduğu için kısaltılarak verilmiştir. Eserin Türkçe kısımlarında zaman zaman Arapça ve Farsça tamlamalar olmakla birlikte sade bir üslupla yazılmıştır. Orta derecede başarılı sayılabilecek olan eserde şair, daha ziyade tercümeye önem vermiş; estetiği ve edebî kaygıyı ikinci plana itmiştir. 
$[3 b]$

\section{METIN}

\section{MANZ̄ŪME-Yİ ḤADĪS̄-İ ERBA'ĪN \\ 1. \\ El-Ḥadīsü'l-Evvel \\ Fãa'ilātün Fä'ilātün Fā'ilün}

Hayru a' māle şurū' itmezden öñ

Niyyet it kim ola maḳbūl-i Hudā

İnne-me'l-a'mālü bi'n-niyyāt ${ }^{4}$ ile

İtdi bu remzi Habīb-i Kibriyā

2.

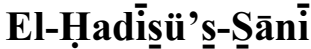

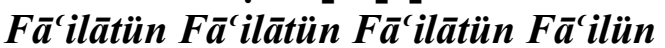

Ömriñi itme telef kesb-i me' ārif eyle

Mehdiden laḥde [de]gin sa ${ }^{c}$ y idegör yā veledī

Ya' ni sultān-ı serā-perde-yi Lev lāk-ı Ahmed

Uțlubü'l-'ilme mine'l-mehdi ile'l-laḥdi ${ }^{5}$ didi

3.

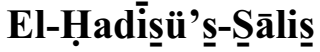

Fā'ilātün fā'ilātün Fā'ilün

Her ne 'ilm ögrenürseñ eyle raḳam

Naḳş ola hātı̣ırıñda tā ebedī

H`āce-yi ' ālem ol Rasūl-i Kerīm

Kayyidi'l-'ilme bi'l-kitābet ${ }^{6}$ didi

4.

El-Ḥadišnu'r-Rābic

Kār-1 zühd ü șalāḥı pisşe idin

Fà'ilätün Fä'ilātün $F \bar{a}^{\prime}$ ilün

İsteriseñ eger-rıżā-yı Hudā

Efżalü'd-dīni'l-verac ${ }^{\text {c }}$ didi ol

Mihr-i nūr-1 efgen sipihr-i Hüdā

5.

El-Ḥadīịü'l-Ḩāmis

Fā'ilātün Fā'ilātün Fā'ilün

Āb-1 luṭf-1la șuvar 'aţ̦ānı kim

Oldurur müstevcibü lutf-1 Hudā

Efżalü'l-a'māli saḳyul māāe ${ }^{8}$ didi

Sāḳi[-i] ' aţ̧̦ān-1 maḥşer Muṣtafāa

\footnotetext{
4 “Ameller niyetlere göredir.” Buhârî Ebû Abdullah Muhammed b. İsmail, el-Câmiü’s-Sahîh, Bedü'l-Vahy, 1.

5 "Beşikten mezara kadar ilim öğreniniz" Hadis değildir. Kelam-1 kibar nev'inden bir sözdür. bk: Kâtip Çelebi, Keşfü'z-Zünün, I, s. 51. Kaynağ 1 tespit edilememiştir.

6 “İlmi yazarak kaydediniz." Hakim en-Nisaburi, El-Müstedrek Ale's-Sahihayn, I, 154 (1/106).

7 "Dinin en faziletlisi takvadır." Hakim en-Nisaburi, age., I, 136 (1/92).

8 “Amellerin en faziletlisi su ikram etmektir.” Ebû Dâvud Süleyman b. Eş'âs es-Sicistânî el-Ez, es-Sünen, Tercüme ve Şerhi, VI, 313. 1681, (Kitübü'z-Zekat: 9, Bab: 41) 
6.

\section{El-Ḥadīsü's-Sādis \\ Fā'ilātün mefā'ilün Fā'ilün}

İtdigüñ luṭı eyleme minnet

Bulasin tā se ādet-i sermed

Buyurur “Āfetü's-simāḥ li'l-menn",

Āfitāb-1 sipihr-i dīn-i Aḥmed

7.

El-Ḥadīsü̈'s-Sābic

Fā'ilātün mefā'ilün Fā'ilün

Sakııın itme dürūg̀̀ diñle sözüm

Olasın halk içinde merd-i güzīn

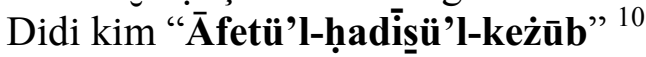

Sebeb-i ḩılḳat-i zemān ü zemīn

[4a]

\section{8.}

Merd-i kezzz̄ābile ḳarīn olma

Fā'ilātün mefā'ilün Fā'ilün

Yoḳdur anda zemāne gibi vefā

Buyurur "Lā mürüvvete li-kezū̄b"11

Sāye-endāz-1 ' ālem-i bālā

9.

\section{Mefā'ìiün Mefãàì̈̈n Fe'ūlün}

Nifāḳ etmek sebebdür züll-i nefse

Bilür bu nükte-yi her merd-i $\bar{a}^{c}$ lam

Buyurmışdur "Nifāḳu'l-mer'i żillet"12

Nebiyy-i muḥterem sulțān-1 ekrem

10.

Hașlet-i buhli gider zātıñdan

Fā'ilātün Fā'ilätün Fā'ilün

Bulasin birr ü şerefle makșūd

Eyleyüp saña keremden ta' lïm

Didi "Lā birra me'a'ş-şaḥḥ" Mahmūd

11.

Mefā'ìlün Mefáciliün Fe'ūlün

Yimegi çok yimekden eyle ḥazer

İrür andan vücūda ża' $\mathrm{f} u$ elem

Didi "Là ṣıḥhate méa'n-nihem"

Hikmet-āmūz-1 ādem ü ' ālem

\footnotetext{
9 “Cömertliğin afeti başa kakmaktır." Celaleddin Abdurrahman b. Ebî Bekr Suyuti, Camiu's-Sağir, Muhtasarı, Tercüme ve Serhi; İmam Muhyiddin-i Nevevi, Riyâzü’s-Sâlihin, s. 995.

10 "Sürekli yalan söyleyenin mürüvveti yoktur." Kaynağı tespit edilememiştir.

11 "Sözün afeti yalan söylemektir." Celaleddin Abdurrahman b. Ebî Bekr Suyuti, age.

12 "Kişinin münafikça davranması alçaklıktır." Kaynağı tespit edilememiştir. Bu mısrada vezin aksamaktadır.

13 “Cimrilik varken sağlık olmaz.” İmam Muhyiddin-i Nevevi, age., C. 1, s. 431.

14 "Oburluk varken rahatlık yoktur." Benzer bir hadis "Bütün ilaçların anası az yemektir” şeklinde İdris-i Bitlisî’nin eserinde geçmektedir. $b k$. Bülent Akot, "Mevlâna İdirs-i Bitlisî ve Manzum Kurk Hadîs Tercümesi: Hadîs-i Çihil" İslâmî Araştırmalar, 2013, 24(2).
} 
12.

Hasedi terk idüp siyādet bul

Fä́ilätün mefä́ilün Fä́ilün

İsteriseñ hużūr-1 ḳalbiñe rāh

Didi "Là rāḥate me'a'l-ḥased"15 ol

Ser-ver-i enbiyā' Ḥabīb-i İlāh

13.

Fãa'ilātün Fā'ilātün Fā'ilātün Fā'ilün

Nefse uyup cehlile sebb ü deyrden ḳ1l ḥazer

Fahr-i 'Ālem nehy idüpdür aç gözüñ eyle ḳabūl

"Lā tesübbü'd-dehra ${ }^{16 "}$ didi ser-ver-i her dü serā ${ }^{17}$

Añlamaz sırr-ı każāyı Vehbiyā her bu'l-fużūl

14.

Fā'ilātün Fā'ilätün Fā'ilün

Kovma derden sầili mạ̣rūm idüp

Kavl-i Ḥaḳka vü Rasūle tụt ḳulaḳ

“Lā teruddü's-sā'ile" ${ }^{18}$ ḳutli eyle

$\mathrm{H}^{\wedge} \bar{a} c e-y i$ her dü serā virdi sebak

[4b]

15.

\section{Fā'ilātün mefä'ilün Fā'ilün}

Sögme hīç kimsenüñ cenāzesine

Budurur şarṭ-1 hāșșa-yı İslām

Buyurur "Lā tesübbü'l-emvāte"19

Ser-ver-i hayl-i enbiyā-yı kirām

16.

Fā'ilātün Fā'ilātün Fā'ilün

Nıṣf-1 dīndür hüsn-i sīret sa ${ }^{c}$ y idüp

Olma emr-i dî̀n ü dünyāda gabì

Gūş-1 cānıñ țut bu kavle mu' cize

Didi “Ḥüsnü̉'l-ḩulḳu nıșfu'd-dīn" ${ }^{20}$ Nebī

17.

Fà'ilātün Fā'ilātün Fā'ilātün Fā'ilün

Kesr-i ḳalb-i mü’min itmekden hazer ḳıl cehlile

'Arş-1 Haḳkı hedm idersin fi'l-ḥakị̣̂a bilmiş ol

Didi "Kạalbü'l-mü'mini 'arşu'llāh'" ${ }^{21}$ Nebiyy-i Muhterem ${ }^{22}$

Arariseñ ḳalb-i mü'minden bulursın Hạḳ̣a yol

15 "Kıskançlık varken rahatlık yoktur.” Kaynağı tespit edilememiştir.

16 “Zamana sövmeyiniz.” Buhârî Ebû Abdullah Muhammed b. İsmail, age., Tefsir-i Sure, 45.

${ }^{17} \mathrm{Bu}$ misrada vezin aksamaktadir.

18 "Soru soranı geri çevirmeyiniz." Abdürrezzak b. Hemmâm, el-Musannef, C:XI, 94.

19 “Ölülere sövmeyiniz." Buhârî Ebû Abdullah Muhammed b. İsmail, age., Cenaiz, 97. Bu mısrada vezin aksamaktadır.

20 "Güzel ahlak dinin yarısıdır." Celaleddin Abdurrahman b. Ebî Bekr Suyuti, Camiu's-Sağir, Muhtasarı, Tercüme ve Serhi; Hadis No: 3070.

21 "Müminin kalbi Rahman'ın arşıdır." Aclûnî İsmail b. Muhammed, Keşfu"l-Hâfâ ve Muzîlü"l-İlbâs Amme"ş-tehera mine"l-Ehâdis fì Elsineti" $n$-Nâs,C.II, s. 100.

${ }^{22} \mathrm{Bu}$ misrada vezin aksamaktadır. 
18.

$F \bar{a}^{\prime}$ ilātün $F \bar{a}^{\prime}$ ilätün $F \bar{a}^{\prime}$ ilün

Kavl-i Vehbìye gūş-1 rag̉bet tut

'İzz-i beḳā ise eger makṣūùd

Şöhret-i dehre olma āşifte

Didi "Eş-şühretü āfet" ${ }^{, 23}$ Maḥmūd

19.

Fā'ilātün Fā'ilātün Fā'ilün

Herze-gūlukdan zebānuñ beste tut

Rāḥat olup bulasin emn ü emān

Siyyemā āgāh idüp didi Rasūl

“Rāḥatü'l-insān fī ḥıfẓı'l-lisān",24

20.

Mefā' ìlün Mefā'î̀iün Fe'ūlün

Emānetdür mecālis ketme sa' $\mathrm{y}$ it

Varup ag̉yārile alma lisāne

Ki zî̀ā ṣadr-1 eyvān-1 risālet

Buyurdı 'El-mecālisü bi'l-emāne",25

21.

İttikāa it mahall-i töhmetden

$F \bar{a}^{\prime}$ ilātün Mefā'ilün Fe'ülün

Çekme ta ${ }^{c} n-1$ hasūd-1 pür-sitemi

Seni ỉkāza idüp buyurdı Rasūl

"İtteḳū min mevāìzı'a't-tühemi"

[5a]

22.

$F \bar{a}^{\prime}$ ilātün $F \bar{a}^{\prime}$ ilätǜn $F \bar{a}^{\prime}$ ilün

Eyle kesb-i halāle diḳkat-i tām

Nükte-den olduñise ger āgāh

$\mathrm{Ne} \mathrm{se}^{\mathrm{a}}$ àdet saña Habīb-i İlāh

Didi "El-kāsibü ḥabību'llāh"27

\section{El-Ḥadisüü's-S̄ālisetü Ve 'İşrūn \\ $F \bar{a}^{\prime}$ ilātün $F \bar{a}^{\prime}$ ilätün $F \bar{a}^{\prime}$ ilün}

Gūş-i dili Vehbī nālāna țut

' Āḳıl iseñ eyle bu nuṣ̣̣ı ḳabūl

İtme țama' zille düşersin șaḳın

"Men țame'a zelle" ${ }^{28}$ buyurdı Rasūl

\footnotetext{
23 "Şöhret afettir." Söz hadis olmayıp kaynaklarda "meşayıh sözü” olarak nakledilmektedir. Ayrıntılı bilgi için $b k$ : Aclûnî İsmail b. Muhammed, age., C. II, s. 206.

24 "İnsanın rahatı diline hâkim olmasındandır." Kaynağı tespit edilememiştir.

25 "Bir mecliste konuşulan sözler emanettir." Ebû Dâvud Süleyman b. Eş'âs es-Sicistânî el-Ezdî, age., Edeb, 32; Beyhaki, el-Medhal ile's-Süneni'l-kübra, X ,414.

26 "Töhmet noktalarında bulunmaktan sakının." Celaleddin Abdurrahman b. Ebî Bekr Suyuti, Camiu'l-Ehadis, C. 1, s. 336.

27 “ (Helal yoldan) kazanan Allah’ın sevgili kuludur.” Aclûnî İsmail b. Muhammed, age., I.349.

28 “Tamah eden zelil olur.” Abdullah er-Rumi Eşrefzade Müzekki'n-Nüfus, s. 179. 
24.

$F \bar{a}^{\prime}$ ilātün $F \bar{a}^{\prime}$ ilätü̈n $F \bar{a}^{\prime}$ ilün

Diḳat ü sa'y eyleyüp her kārıña

Eyle hüsn-i ' iş içün tedbīr-i tām

Didi “Et-Tedbïru nıșfu'l- 'iş"29 işit

Ol Ḥabīb-i Muḥterem Faḩru'l-Enām

25.

Fā'ilātün Fā'ilātün Fā'ilün

Eyledigüñ cürmi añup nādim ol

Kalmaya pes perde-yi noḳsānanda

Didi Nebī "En-nedamü tevbetün",30

Olma muṣırr hạṣ̣̂lı 'iṣyānda

26.

Mefā' ìlün Mefā'î̀iün Fe'ūlün

Hazer ḳ1 deyne girme girerseñ

Edāsına teḳayyüd eyle fi'l-ḥāl

İşit “Ed-deynü şeynü'd-dìn" 31 Hadīsin

Edầ-yı deyn olupdur dīnüñe dāl

27.

Fā'ilātün Fā'ilätün Fā'ilün

Gel işit luṭını meșāliḥanuñ

İtme herkesle da'vāya iḳdām

Ki Rasūl-i Hudā-yı 'Azze ve Cell

Didi "Eṣ-ṣulḥu seyyidü'l-aḥkām,"32

28.

Fā'ilātün Fā'ilätün Fā'ilün

Eyleme hande-yi bī-hūde'i çok

Ki irişür mevt-i fücā'i ḳalbi

Şeh-i iḳlīm-i nübüvvet didi kim

[5b]

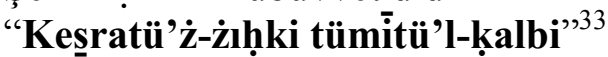

29.

Fā'ilātün Fā'ilātün Fā'ilātün Fā'ilün

Ülfet-i cāhil ile virme vücūda külfet

Șulehạa ṣoḥbetine varır iseñ var ruhṣat

Didi "El-vahdetü ḩayrun" 34 şeh her dü serā

Fi'l-mesel[dür] dūzaḩa cehlile șoḥbet

29 “Tedbirli olmak geçimin yarısıdır.” Ebu Abdullah Muhammed Bin Selame Bin Ca’fer Kudai, Müsnedü'ş-Şihab, s. 54.

30 "Pișmanlık tövbedir." Ahmed b. Hanbel, El-Müsned, I/376, 423.

31 "Borç dindarlığın lekesidir.” Ebu Abdullah Muhammed Bin Selame Bin Ca'fer Kudai, age., s. 53.

32 "Barış hükümlerin efendisidir.” Rebi'b Bin Habib, El-Câmiüs's-Sahih Müsnedü'l-İmam Er-Rebi' Bin Habib, C. 1, s. 235.

33 “Çok gülmek kalbi öldürür.” Tirmizi, Zühd, C.2, Ahmed Bin Hanbel, Müsned, 7748. Câmî ve Fuzûlî

34 “Birlik hayırdır." Beyhaki, Şuabi’l-İman, XIII, s. 341. 
30.

Fā'ilātün Fä'ilätün $F \bar{a}^{\prime}$ ilün

Sakıınup hịileye mu' tād olma

Ṭolaşur ayaġıña āhır-i kār

Diñle "Men gașşe fe-leyse minnā"

Nüktesin gözüñi aç cānıñ uyār

31.

İderseñ keremā va' $d \ddot{u ̈ ~}^{\text {'atā }}$

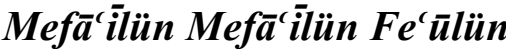

Halḳı terk it sözi eyle kabūl

Virmesi vācib olur mev' $\bar{u}^{\prime} 1$

Dimedi mi "El-'detu deynun" ${ }^{, 36}$ o rasūl

32.

Fā'ilātün Mefā'ì̄iün Fā'ilün

Sirr-1 aḥbābıñı dime halḳa

İhfezu's-sırra enne-hū ḥasenün

Kavl-i sulțān-1 enbiyāyı işit

Didi "El-müsteşāru mü’temenün",37

33.

Fā'ilātün Fā'ilātün Fā'ilün

Hedāyā sebebdir şikār dile

Ṭuta nuṣh-1 Vehbīye gūş-1 ḳabūl

Sehā-ver şeref-bahş-1 Ādem ki zīrā

"Tehāddū teḥābbū ${ }^{38}$ buyurdı Rasūl

34.

Fā'ilātün Fä'ilätün Fā'ilün

Cennete reh-ber olur saña konuk

Men` i nās idüp nārı mis̄āl-i cenne

$\mathrm{H}^{\wedge} \bar{a} c e-y i$ her dü serā, kān-1 'atā

Didi "Ė̇z-żayfu delīlü'l-cenne",39

35.

Saña itmezse țâlic iñ yārì

Fā'ilātün Mefā'ì̈lün Fà'ilün

Çekme bī-hūde renciş-i țalebi

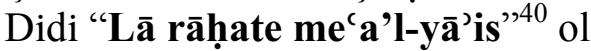

Şeh-i Mekkì Muhammed 'Arabī

\footnotetext{
35 “Aldatan bizden değildir.” Tirmizî Ebu İsâ Muhammed b. İsa, El-Câmiü’s-Sahih; Sünenü 't-Tirmizi, 1315.

36 "Söz senettir." Ebu Abdullah Muhammed Bin Selame Bin Ca'fer Kudai, age., C. 1, 40.

37 "İ̀stişare edilen emindir." Tirmizî Ebu İsâ Muhammed b. İsa, age.

38 "Hediyeleşin ki birbirinize sevginiz artsın." Ebu Abdullah Muhammed Bin Selame Bin Ca'fer Kudai, age., C. 1, s. 381.

39 "Misafir cennetin kılavuzudur." Kaynağı tespit edilememiştir.

40 "Ümitsizlik varken rahat olmaz.” Kaynağı tespit edilememiştir.
} 
[6a]

36.

Mefā'ì̄lün Mefā'ì̄lün Fe'ūlün

Saḳın ' aynü'l-kemāle olma manẓar

İrür āyīneñe zīrā kedūret

Buyurmuşlardurur "El-‘aynü haḳḳun"41

O mihr-i tāb-dār-1 evc-i rif $a t^{t}{ }^{4 \dot{2}}$

37.

Fā'ilātün Fā'ilätün Fā'ilün

Çünki gördüñ nā-sezā itme sükūt

Telh ise de haḳkı söyle it ḳabūl

Gel "Kuli’l-ḥaḳka ve lev mürran"43 sözin

Diñle cānile buyurmışdur Rasūl

38.

İki şahșuñ arasın bul șulh it

Fā'ilātün Fā'ilātün Fā'ilün

Ne deriseñ di ki virmez saña şeyn

Muṣliḥa müjde idüp Şāh-1 Rusul

Didi “Men eṣleḥa beyyene'l-išneyn"44

39.

Fā'ilātün Fā'ilätün Fā'ilün

Alma ele bāde-yi pür-ḥurmeti

Gafletile nef ${ }^{r}$ ine virme vücūd

Didi kim "El-ḩamru cimāc'u'l-āșim",45

Mebde'-i küll şāh-1 rusul baḥr-i cūd

40.

Fā'ilātün Mefā'ì̈lün Fä'ilün

Saña ceng it dimem tehevvür eyle

Düşer ise ' adūya meyl-i cihād

Didi "El-ḥarbu huud'atün"46 Mạ̣mūd

Erlik it hịile ile bul ỉrād

41 "Nazar haktır." Müslim Ebu'l-Hüseyn b. Haccâc, el-Câmiu's-Sahîh, Selâm: 42; İbn Mâce Ebû Abdullah Muhammed b. Yezd el-Kazvinî, Es-Sünen, Tıb: 3. Usûlı̂'nin eserinde de yer almaktadır. bk. Adem Ceyhan, "Usûlî’nin Hadis ve Vecize Tercümeleri”, İstanbul Üniversitesi Edebiyat Fakültesi Türk Dili ve Edebiyatı Dergisi, 2001-2003.

${ }^{42}$ Bu misrada vezin aksamaktadır.

43 "Acı da olsa doğruyu söyleyiniz.” Ebu Abdullah Muhammed Bin Selame Bin Ca'fer Kudai, age., 5/159.

44 "İki kişinin arasını bulan.” Buhârî Ebû Abdullah Muhammed b. İsmail, age., Sulh: 2.

45 “İçki bütün kötülüklerin anasıdır." Celaleddin Abdurrahman b. Ebî Bekr Suyuti, Câmius'sağîr, Hadîs No: 4141.

46 "Harp hiledir." Buhârî Ebû Abdullah Muhammed b. İsmail, age., Cihad, 157. 


\section{HĀTİME \\ Mefấî̀iün Mefâ'î̀lün Fe'ūlün}

1. Ehādīis-i Nebiyy-i Hayr-i Ümmet

İdüp encāma ḩāme yazdı temmet

2. Temām olur eger ' ayn-1 ' ināyet

Açar rūyına bir ehl-i himmet

3. 'Uyūb-1 gühterānı setr iderler

Kerīmü'l-halḳ olan erbāb-1 hịmet

4. Ġaraż hayr du' ādır cüst ü cūdan

Dirìg itme ne deñlü olsa zahmet

5. Oḳursa bir șadāḳat-pişse-yi ' āşık

Umarum oḳuya Vehbijye rạmet

6. Bi-ḥakkk-1 āb-1 rū-yı fahr-i millet

Buña 'izzet idenler bula raḥmet

7. İde dünyā vü 'uḳbada şefā' at

Şefíc-i mücrimān-1 hayr-i ümmet 


\section{Kaynaklar}

ABDULLAH ER-RUMİ EŞREFZADE. (2006). Müzekki'n-Nüfus. (haz. Abdullah Uçman). İstanbul: İnsan Yayınlar1.

ABDÜRREZZAK B. HEMMÂM, (2013). el-Musannef, I-XII. İstanbul: Ocak Yayıncılık.

ACLÛNÎ İSMAIIL B. MUHAMMED, (1988). Keşfu'l-Hâfâ ve Muzîlü'l-ïlbâs Amme'ş-tehera mine'l-Ehâdis fî Elsineti'n-Nâs, I-II. Beyrut.

AHMED B. HANBEL, (1389). Müsned I-VI. Beyrut.

AKOT, B. (2013). Mevlâna İdirs-i Bitlisî ve Manzum Kırk Hadîs Tercümesi: Hadîs-i Çihil. İslâmî Araştırmalar Dergisi, 24, 71-84.

AKSU, C. (2004). Hanif' in Manzum Kırk Hadis Tercümesi Şerhi. İlmî Araştırmalar, 17, 7-34.

ALTUNER, N. (1989). Safai ve Tezkiresi. Doktora Tezi, İstanbul: İstanbul Üniversitesi Edebiyat Fakültesi Türk Dili ve Edebiyatı Bölümü Eski Türk Edebiyatı Anabilim Dalı Sosyal Bilimler Enstitüsü.

BANARLI, N. Sami (1971). Resimli Türk Edebiyatı Tarihi. İstanbul: Milli Eğitim Bakanlığı Yayınları.

BEYHAKİ, (1986). El-Câmi' li-Şuabi'l-İman. ed-Dârü's-Selefiyye, Bombay.

BEYHAKİ, el-Medhal ile's-Süneni'l-kübra. [Hazırlayan]: Muhammed Ziyaurrahman A'zami, Dârü'l-Hulefa li'l-Kitâbi'l-İslamiyye, Kuveyt.

BUHÂRÎ EBÛ ABDULLAH MUHAMMED B. İSMAİL, (1981). el-Câmiü's-Sahîh, I-VIII, İstanbul.

BURSALI MEHMED TAHIIR (1972), Osmanlı Müellifleri. [Hazırlayan]: A.Fikri Yavuz-İsmail Özen, C.II, İstanbul: Meral Yayınevi.

CELALEDDIN ABDURRAHMAN B.EBÎ BEKR SUYUTİ, Camiu'l-Ehadis (1515), [Hazırlayan]: Hasan Abbas Zekî, Matbaatu Hattab.

CELALEDDİN ABDURRAHMAN B. EBÎ BEKR SUYUTİ. Camiu's-Sağir, Muhtasart, Tercüme ve Şerhi, [Hazırlayan]: İsmail Mutlu, Şaban Döğen, Abdülaziz Hatip (1996). İstanbul: Yeni Asya Yayınları.

CEYHAN, A. (2001 - 2003). Usûlı’’nin Hadis ve Vecize Tercümeleri. İstanbul Üniversitesi Edebiyat Fakültei Türk Dili ve Edebiyatı Dergisi, C.XXX, 147 - 188.

DİKMEN, H. (1991). Seyyid Vehbî ve Divanının Karşılaştırmalı Metni, Basılmamış Doktora Tezi Ankara: Ankara Üniversitesi Sosyal Bilimler Enstitüsü.

DÍKMEN, H. (2004). Seyyid Vehbi'nin Hayatı, Eserleri ve Sanatçı Kişiliği. Ç.Ü. Illahiyat Fakültesi Dergisi, C.4, Sayı 1, Ocak-Haziran, 1-22.

EBU ABDULLAH MUHAMMED BİN SELAME BİN CA'FER KUDAİ, (1985). Müsnedü'şŞihab, Müessesetü'r-Risâle, Beyrut.

EBÛ DÂVUD SÜLEYMAN B. EŞ’ÂS ES-SİCİSTÂNÎ EL-EZDÎ, (1969). es-Sünen, I-V, Hıms.

GIYNAŞ, K. A. (2012). Hilâlı̂’nin Mazum Kırk Hadis Tercümesi. Turkish Studies Volume 7/1 Winter, 1133-1157.

HAKIM EN-NISABURI, El-Müstedrek Ale's-Sahihayn, [Hazırlayan]: M. Beşir Eryarsoy (2013), Konya: Konevi yayınları. 
İBN MÂCE EBÛ ABDULLAH MUHAMMED B. YEZD EL-KAZVINÎ, (1952). es-Sünen, III.

İMAM MUHYIDDIN-İ NEVEVİ, Riyâzü's-Sâlihin. [Hazırlayan]: Sitkı Gülle, İstanbul: Olcu Yayınları.

İNCE, A. (2005). Tezkiretü’ş-Şu'arâ Sâlim Efendi. Ankara: Atatürk Kültür Merkezi Başkanlığı Yayınları.

KARAHAN, A. (1966). Seyyid Vehbî. İslam Ansiklopedisi, C.X, İstanbul: Milli Eğitim Basımevi, 543-547.

KARAHAN, A. (1991). İslami Türk Edebiyatından Kırk Hadis. Ankara: Diyanet İşleri Başkanlığı.

KÂTİP ÇELEBİ, Keşfü'z-Zünün, [Hazırlayan]: Mehmet Şerafettin Yaltkaya (1941), Ankara: Millî Eğitim Bakanlığı, C.I.

KAYNARCA, A. Tuba (2000). Seyyid Vehbî'nin Surnâmesi: İnceleme-Metin. Basılmamış Yüksek Lisans Tezi, Kütahya: Dumlupınar Üniversitesi Sosyal Bilimler Enstitüsü.

KOÇU, R. Ekrem (1939). Sûr-nâme. İstanbul.

KURNAZ, C. (1997). Dinî Edebiyat Türleri ve Dinî Edebiyatımızın Bugünü Hakkında Düşünceler. Divan Edebiyatı Yazıları, Ankara: Akçağ Yayınları, 271-289.

MÜSLIM EBU'L-HÜSEYN B. HACCÂC, (1955). el-Câmiu's-Sahîh, I-V. Misır.

REBI'B BİN HABİB, El-Câmiüs's-Sahih Müsnedü'l-İmam Er-Rebi' Bin Habib.

SEVGİ, A. (2000). Molla Câmî'nin Erba'în'i ve Manzum Türkçe Tercümeleri. Konya.

SEVGİ, A. ve ÖZCAN M. (1996). Prof. Ali Canip Yöntem’in Eski Türk Edebiyatı Üzerine Makaleleri. İstanbul: Sözler Yayınları.

SEYYID VEHBÎ, Hadis-i Erba'in Tercümesi. İstanbul Üniversitesi Nadir Eserler Kütüphanesi, TY:1376, 3b-6a.

SEYYID VEHBÎ, Sulhiyye. İstanbul Üniversitesi Nadir Eserler Kütüphanesi TY:2711, vr.220b$229 b$.

TİRMIZÎ EBU İSÂ MUHAMMED B. İSA, (H.1292). El-Câmiü's-Sahih; Sünenü't-Tirmizi. Kahire: Matbaatü'l-Amire.

TİRMIZÎ EBU İSÂ MUHAMMED B. İSA, es-Sünen, I-V. Kahire 1938-1962.

YILDIRIM, S. (2000). Osmanlı'da Kırk Hadis Çalışmaları 1. İstanbul: Darulhadis. 